\title{
New Periodicals of 1943-Part II
}

Miss Ulrich's post is that of chief of the Periodicals Division of the New York Public Library.

$F^{2}$ EWER NEW PERIODICALS of importance have appeared during the past six months than in any other similar period for many years. As the war continues there can be little doubt that the magazine world will suffer further depletion. Several publishers of magazines in the scientific and technical field, because of the shortage of staff and wartime rationing of paper, already have been compelled to control subscriptions for the duration of the war and orders will not be accepted from libraries or other groups outside of a given specialized field. If this situation leads to the inability of libraries to complete files of scientific and historical source material in their collections after the war, it will leave a serious scar in all research libraries, unless a microfilm or other postwar edition of back issues is made available. For the individual it becomes more and more apparent that the student engaged in research concerned with the immediate activities of the world will be handicapped by inaccessibility to the knowledge of new developments, primarily in the fields of science and technology, which are found chiefly in periodicals.

Although a few scholarly publications in the humanities have appeared and some interesting and varied representations from Latin America, the larger group of new magazines is again in the field of scientific and technical advancement for the war effort. Aviation News, a weekly, is designed to give the latest information of what the industry is performing and, looking ahead, interprets the significance of the industry's expansion in postwar aviation. There are photographic illustrations and descriptive drawings. Air Transport will keep the reader abreast of the rapid and growing development in this branch of aeronautics caused by the urgency of both civil and military transportation demands for speed and precision in carrying men, equipment, and materials. Illustrations, diagrams, and charts are given. Still another phase of aeronautics is the Universal Airline Schedules, which contains schedules of all airplane lines, data about United States and international travel, air mail, exchange rates, and cargo information. Business and reference libraries will find it a most useful tool.

Turning to allied fields Plastics $W$ orld supplies news and information about new materials, resins and synthetics, new processes, equipment, and applications. It is of importance to those interested in the brilliant inventiveness of the plastic world. New literature and catalogs on the subject are listed. The Pacific Plastics Magazine covers similar material with emphasis on the industry in the 
Pacific Coast area. In the use of prefabrication materials unusual mass production in housing has been accomplished for the war industrial workers and the armed forces. This industry is undergoing a rapid expansion. Prefabricated Homes gives accounts of methods of production and ways by which they are constantly being improved, the new materials used, and the necessary equipment developed. In fact, information about all the varied aspects of the fabrication of housing is included with good illustrations, plans, charts, and diagrams. Light Metal Age, a publication in an industry of modern experimentation, is devoted to production, fabrication, application of magnesium, aluminum, beryllium, and light alloys. Information is given of results from research study and experimentation in the field of the light metal industry. It contains prices, lists new literature including pamphlets and catalogs, and is indexed in Chemical Abstracts.

Of great importance in the economic field are the increased number of government publications which cover pertinent subjects in war production, such as agricultural economics, food distribution, products and priorities, petroleum, labor management, etc. Economic Sentinel, published by the Los Angeles Chamber of Commerce, contains in each issue a study by a specialist on problems of vital and timely subjects. The first issue discusses "Wartime Food Management," an analysis with recommendations by Joseph S. Davis, Director, Food Research Institute, Stanford University, Calif.

\section{Inter-American Periodicals}

Three periodicals soundly sponsored and well edited mark a most intelligent outcome in this country of the progress of coordination between North and South America. Acta Americana, an international quarterly, is published by the Inter-American Society of Anthropology and Geography. This new society, recognizing the "vast and increasing amount of research on American problems [of anthropology and geography], calls for synthesis and interchange of information." The society is affiliated with many of the oldest and noted societies of the continent, among them the American Ethnological Society of New York. The main purposes of the review are "to provide a medium for the exchange of ideas, methods, and results and to draw together geographers, anthropologists, and persons with related interests throughout the Americas into a closer union." Articles are in Spanish, Portuguese, and English, with bibliographic references at the end of each article. Illustrations, abstracts, and book reviews are given. Another scholarly publication is Tlalocan, a journal of source material on the native cultures of Mexico-the whole area formerly embraced by New Spain. The introduction states that the aim is to include "material which will contribute to an understanding and appreciation of the Indian people." Its topics are to be native language texts of historical, anthropological, or linguistic importance accompanied by Spanish, French, German, or English translations. It contains bibliographies for further study and signed book reviews, is well printed, and has an excellent format. The editorial advisers are from the National University of Mexico, Department of Ethnology of the National Museum of Mexico, Black Mountain College in North Carolina, and Department of Geography, University of California. Notes on Latin American Studies has as 
its main purpose that the publication "will serve to give integration to Latin American studies in the humanities and social sciences and provide a medium for consideration of problems of teaching and research." It is sponsored by the National Research Council, American Council of Learned Societies, and Social Research Council.

From the University of California are two new monograph series: Publications in Political Science and Publications in Linguistics. Both are scholarly contributions and of importance to the fields of knowledge concerned.

The Southern Weekly is a promising and well-edited publication confining its scope to the common economic and political interests of the Southern states. Of note is a department "Views of the Southern Press," expressing Southern editorial opinion. The Transatlantic, a general monthly magazine about America published in London, contains, with the exception of a column of comment by the London editor Geoffrey Crowther, material written by Americans about the United States. Among the contributors are Walter Lippmann, Elsworth Huntington, D. W: Brogan, Frederick Lewis Allen, Carl Van Doren, Ogden Nash, and Carl Carmer. Roscoe Drummond, Washington correspondent of the Christian Science Monitor, will report regularly from Washington. Its aim is to promote a better understanding between Great Britain and the United States. Fully illustrated.

The American Indian, published by the American Association on Indian Affairs, "is devoted to the interests of the Indians of North America. Its primary purposes are to increase its readers' knowledge of those Indians, to defend their rights from attack, and to increase the desire of American citizens to better their condition." A Monthly Summary of Events and Trends in Race Relations, published for the Julius Rosenwald Fund, is a critical study of the Negro based on direct reports from important centers in the United States. It contains abstracts from newspapers and magazines, Negro and white, from all parts of the country. There are also good book reviews.

\section{Literary Periodicals}

Hemispheres, a new "Little Review" with text in English and French, is edited by Yvan Goll. The first issue contains writings of modern American, English, and French poets and critics prominent in the fields of experimental writing. Emphasis is laid on poetry in its relation to a war-torn world. Contributors of poetry in English are George Barker, Charles Henri Ford, William Carlos Williams, Kenneth Patchen, and Dunstan Thompson; in French are Saint-John Perse, Yvan Goll, and Alain Bosquet. Parker Tyler contributes an essay. Living Poetry, also a "Little Magazine," is devoted exclusively to poetry. In it are found the poems of Thomas Curtis Clark, Gustav Davidson, Glenn Ward Dresbach, and Clement Wood. The magazine is interested not so much in emphasizing poetic utterances as in expressing the "more subtle absorption [of poetic appreciation] into the existence of all human beings." The first issue of the Quarterly Review of Literature includes an interesting selection of modern international writers. Contributions include poetry of E. E. Cummings and of two South American poets, Profirio Barba Jacob and Jorge Carrera Andrade; fiction by Paul Green; articles by Carlos Garcia-Prada, 
H. C. Montgomery, and others. Now is an experimental publication from England. This name was transferred from a "Little Review" started in 1940, but the periodical bears no connection to the earlier publication. The new magazine contains literary and social writings and is edited from an anarchistic point of view. The book reviews are by Julian Symons.

Among recent Latin American publications several are notable. Humanidades is the organ of the graduate students in philosophy and literature at the Universidad de Mexico. The format, paper, and printing are good and it contains signed book reviews. El Hijo Pródigo is a new and promising review of distinction with emphasis on literature and art. Unique in its printing and editing it is well illustrated and attractive in format. Domani is another cultural review published in
Buenos Aires by liberal Italian exiles with the text in Italian. It has a pleasing format and is printed on good paper with a few illustrations. Cámara del Libro de Chile Boletin is sponsored by the Chilean book trade for the purpose of advertising books printed in Chile. Libraries will find it useful in adding new titles to their collections. In the archeological field, Registro de Cultura Yucateca is devoted to the study of the Mayan antiquities in Yucatan. Museo Arqueologico de Colombia Boletín is a small, illustrated publication on archeological and anthropological findings in Colombia. Lastly, Rivista de la Universidad de Puebla is a journal which aims to make known the scientific investigations of both students and professors of the university. Considerable information is given about the university and its curriculum.

\section{Periodicals}

Acta Americana. Inter-American Society of Anthropology and Geography, Smithsonian Institution, Washington, D.C. v. I, no. I, April-June I 943. Quarterly. Membership.

Air Transport. McGraw-Hill Publishing Company, Inc., $330 \mathrm{~W}$. 42nd St., New York City I8. v.r, no. I, September 1943. Monthly. \$5.

The American Indian. American Association on Indian Affairs, Inc., 38I Fourth Ave., New York City I6. v. I, no. I, November 1943. Quarterly. \$2. Aviation News. McGraw-Hill Publishing Company, Inc., 330 W. 42nd St., New York City I 8. v. I, no. I, Äugust i943. Weekly. \$5.

Camara del Libro de Chile Boletin. Casilla rar 1 r, Santiago de Chile. v. I, no. I, I943. Frequency and price not given.

Domani. Paolo Vita-Finzi, Posadas I041, Buenos Aires. v. I, no. I, April-June 1943. Quarterly. Io pesos.

Economic Sentinel. Chamber of Commerce, Los Angeles. v. I, no. I, Aug. I I, I 943. Frequency and price not given.

Hemispheres: French American Quarterly of Poetry. I 36 Columbia Heights, Brooklyn. v. I, no. I, summer I943. \$1.75.

El Hijo Pródigo; Revista Literaria. Apartado postal ro94, Mexico, D.F. v. I, no. I, April r 943. Monthly. \$I 5 Mex.

Humanidades; Organo de los Alumnos de la Facultad de Filosofía y Letras. Universidad Nacional Autonoma de Mexico, Mexico, D.F. v. I, no. I. July I 943. Frequency and price not given.

Light Metal Age. 20 E. Jackson Blvd., Chicago 4. v. I, no. I, 1943. Bimonthly. Price not given.
Living Poetry. 506 Maple Ave., La Porte, Ind. v. I, no. I, autumn I943. Quarterly. \$I.

$A$ Monthly Summary of Events and Trends in Race Relations. Social Science Institute Fisk University, Nashville, Tenn. v. I, no. I, August I943. Price not given

Museo Arqueologico de Colombia Boletin. Ministerio de Educacion Nacional, Bogota. v. I, no. I, February 1943. Frequency and nrice not given.

Notes on Latin American Studies. Joint Committee on Latin American Studies, 55 Hillhouse Ave., New Haven, Conn. v. I, no. I. April I943. Semiannual. (With occasional special issues.) \$I. Now. Freedom Press Publications, 27 Belsize Road, London, N.W. 6. v. I, no. I, I943. Irregular Is. 6d. per no.

Pacific Plastics Magazine. Institute Press, I3 I4 W. Ninth St., Los Angeles i 5. v. I, no. I, June I 943 Ninth St., Los Angeles I 5. v. I, no. I, June 1943. Monthly. \$3.

Plastics World; New Materials, Equipment, Applica tions. Cleworth Publishing Company, Inc., 55 Fifth Ave., New York City. v. I, no. I, April I943. Monthly. \$3.

Prefabricated Homes. Illumination Publishing Com. pany, Inc., I 4 E. 3 and St., New York City. v. I, no. I, April I 943. Monthly. \$2.

Quarterlv Review of Literature. Box 752, Chapel Hill, N.C. v. I, no. I, autumn I 943 . \$3.

Registro de Cu'tura Yucateca. Jose Diaz Bolio, Guanajuato I 84, Mexico, D.F. v. I, no. I, I 943. Frequency and price not given.

Revista de la Universidad de Puebla. 4 Sur 104, Puebla, Pue., Mexico. v. I, no. I, May I943. Bimonthly. Price not given. 
Southern Weekly. Molyneaux-Lewis Publishing Company, P.O. Box 2089, Dallas I. v. I, no. I,

Oct. 16, 1943. \$5.
Tlalocan; A Journal of Source Materials on the Native Cultures of Mexico. House of Tlaloc, Sacramento, Calif. 4 issues a year. \$4.

Transatlantic. Penguin Books Limited, West Dray-

ton, Middlesex. v. I, no. I, September 1943 .

Monthly. 13s. 6d.
Universal Airline Schedules. 139 N. Clark St., Chicago. v. I, no. I, April 1943. Monthly \$5. niversity of California Publications in Linguistics. niversity of California Publications in Linguistics.
University of Californa Press. Berkeley. v. I, no. I, July 6, 1943. Irregular. Price varies.

University of California Publications in Political Science. University of California Press, Berkeley. v. 1, no. 1, June 15, 1943. Irregular. Price varies.

\section{College and University Library News}

\section{(Continued from page 155)}

State, ${ }^{220}$ Mary Gaver at Trenton, N.J. ${ }^{221}$ Leroy C. Merritt at Farmville in Virginia, ${ }^{222}$ Charles $\mathrm{H}$. Stone at Georgia, ${ }^{223}$ Marshall Stewart at Memphis in Tennessee, ${ }^{24}$ Mary J. Ryan at Eastern in South Dakota, ${ }^{225}$ and Ralph Fritz at Pittsburg in Kansas, where with an avowed view to pedagogical results the

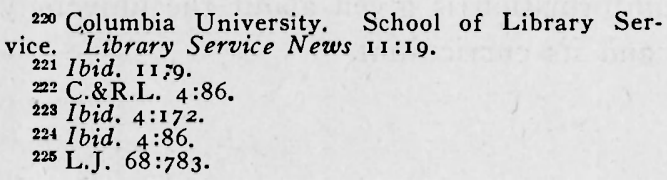

\section{Graduate Library}

The Graduate Library School of the University of Chicago will offer three fellowships of one thousand dollars each for the I944-45 academic year. The fellowships are for advanced study leading to the M.A. and Ph.D. degrees and are in addition to several scholarship awards to be made for study leading to the bachelor of library science degree.

The following attainments are required of applicants for fellowships:

(a) Possession of a bachelor's degree equivalent to that conferred by leading colleges and universities. librarianship is being combined with a professorship of education. ${ }^{226}$ Guy R. Lyle spent a year's leave from the Woman's College of North Carolina in teaching at the University of Illinois Library School. ${ }^{227}$ Arthur E. Gropp, librarian of the Middle American Research Institute at Tulane, has been sent to Montevideo to organize there a library representing the culture of the United States. ${ }^{228}$

220 S.\&S. $58: 343$

227 C.\&R.L. 4:86; W.L.B. $17: 334$

228 W.L.B. $17: 246$.

\section{School. Fellowships}

(b) Completion of at least one year in an accredited library school.

(c) At least one year of library experience under approved conditions.

Special consideration will be given to publications and manuscripts showing ability to conduct original studies.

Forms to be used in making application for admission and for fellowships may be obtained by writing the Graduate Library School, University of Chicago, Chicago 37. Applications must be in the hands of the dean of the Graduate Library School on or before Mar. IO, I 944. 